\title{
自己伝播発熱素材を用いた瞬間はんだ接合技術
}

\author{
生津 資大 *
}

\section{Reactive Soldering Technique Using Self-Propagating Exothermic Material}

Takahiro NAMAZU*

*兵庫県立大学 (T 671-2201 兵庫県姫路市書写 2167)

*University of Hyogo (2167 Shosha, Himeji, Hyogo 671-2201)

\section{1. はじめに}

ナノのサイズを持つ材料は, バルクでは見られなかった 新たな機能や現象を発現することが多い。例えば, マイク ロ〜ナノサイズに成形した単結晶 $\mathrm{Si}$ は $100 \sim 300^{\circ} \mathrm{C}$ 程度で 塑性変形現象を示す (一般的にはバルク単結晶 $\mathrm{Si}$ は $600^{\circ} \mathrm{C}$ 以上で塑性変形することが知られている）ことなどが相当 する ${ }^{1)}$ 。このようなマイクロ〜ナノ材料特有の現象は学術 的に大変興味深く, 多くの研究者がサイズ効果の完全解明 を目指している。また, サイズ効果現象は単に学術的に面 白いだけでなく，新たな製品を創出するきっかけとなり得 ることもある。著者らはこれまで軽金属と遷移金属を数十 $\mathrm{nm}$ ずつ積層堆積させた金属多層膜が自己伝播発熱反応 ${ }^{\dagger}$ を 示すことを見出し，その瞬間的な発熱特性を利用して Si ウェハを 0.1 秒未満に瞬間はんだ接合する技術を開発して きた。この技術を使うと限られた領域のみを極短時間で接 合できるため, 耐熱性の低い電子デバイスや MEMS (Micro Electro Mechanical Systems) デバイスの封止実装に有用と期 待できる。

本報では，まず， $\mathrm{Al} / \mathrm{Ni}$ 多層膜を用いて自己伝播発熱反 応について概説する。次に, $\mathrm{Al} / \mathrm{Ni}$ 多層膜の成膜条件と発 熱特性の関係を記した後, これまで実施したはんだ接合応
用研究の成果の一部と技術課題を紹介する。

\section{2. 自己伝播発熱多層膜}

軽金属と遷移金属をナノの厚みで積層堆積させた金属多 層膜は，自己伝播発熱反応を示す。この多層膜に外部から 極微小エネルギを与えると，2つの金属による化合物生成 と同時に橙色の閃光を発しながら発熱する（図 1)。局所的 な化合物生成反応で生じた熱が次の反応誘起のためのエネ ルギとして使われるため, この発熱反応は多層膜内を 10 $\mathrm{m} / \mathrm{s}$ 程度で高速自己伝播する ${ }^{2)}$ 。

図 2 より, バイレイヤー厚 20〜 $100 \mathrm{~nm}$, 総膜厚 $20 \mu \mathrm{m}$ の $\mathrm{Al} / \mathrm{Ni}$ 多層膜はいずれも発熱反応を示し，発熱ピークの位 置と数はバイレイヤー厚で異なることがわかる。例えば, バイレイヤー厚 $100 \mathrm{~nm}$ の $\mathrm{Al} / \mathrm{Ni}$ 多層膜では 3 つの発熱ピー クが見られ，温度が低い方から $524 \mathrm{~K} ， 590 \mathrm{~K}, 675 \mathrm{~K}$ でそ れぞれ $\mathrm{Ni}_{2} \mathrm{Al}_{9}, \mathrm{NiAl}_{3}, \mathrm{NiAl}$ の金属間化合物が生成した。こ のグラフの横軸を時間に置き換え，発熱ピークの面積を算 出すると, 図 3 に示すように単位質量当たりの反応熱量が 得られる。反応熱量は 2 種の金属の組み合わせ，バイレイ ヤー厚，総膜厚などで決まり，スパッ夕成膜したバイレイ ヤー $100 \mathrm{~nm}$, 総膜厚 $40 \mu \mathrm{m}$ の $\mathrm{Al} / \mathrm{Ni}$ 多層膜（原子比 $1: 1 ） の$ 場合, 約 $1,200 \mathrm{~J} / \mathrm{g}$ の熱量を放出する。バイレイヤーが薄く

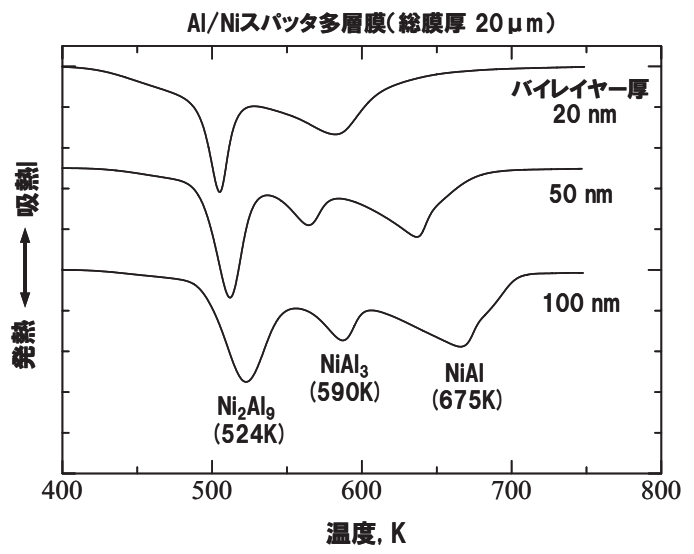

図 2. $\mathrm{Al} / \mathrm{Ni}$ スパッタ多層膜の示差走査熱量計測結果の一例 


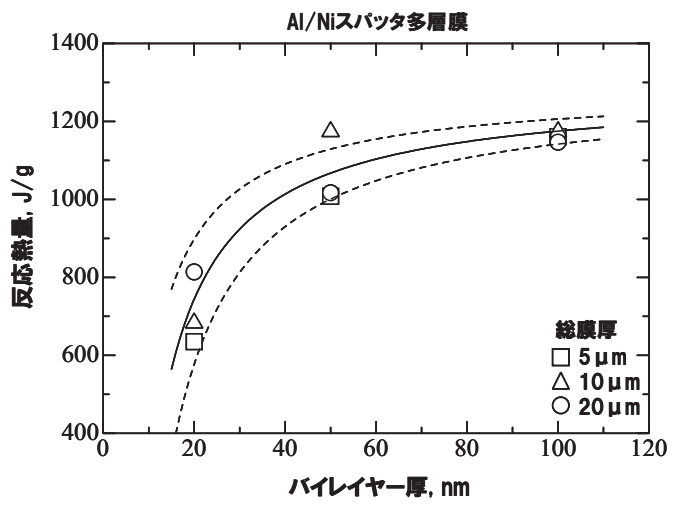

図 3. Al/ $\mathrm{Ni}$ スパッタ多層膜における単位質量あたりの反応 熱量のバイレイヤー厚依存性

なると単位質量当たりの発熱量が減少する原因は, 多層膜 には $\mathrm{Al}$ 層と $\mathrm{Ni}$ 層の間にミキシング層と呼ばれる混合層が 存在することと関係する。ミキシング層は発熱反応しない ことから, バイレイヤー厚低下とともにミキシング層の割 合が増え, 結果として図3 のような傾向が得られる。ま た, $\mathrm{Al} / \mathrm{Ni}$ 多層膜（原子比 $1: 1$, バイレイヤー100 nm, 総膜 厚 $40 \mu \mathrm{m}$ ）を短冊状のカプトンテープ上に成膜し，一端に 電気刺激を与えて反応を誘起させ, 他端への反応伝播時の 温度を赤外線放射温度計で計測すると, 0.1 秒で $1,000^{\circ} \mathrm{C}$ 近 くまで瞬間発熱する。最高温度到達の数秒後には室温まで 低下するため, この発熱素材を用いると, 熱を与えたい箇 所の久を瞬時に加熱できる。自己伝播発熱反応は酸化還元 反応ではないために反応雲囲気を選ばず, 真空中, 不活性 ガス中, 水中でも大気中と同様に反応する。加えてアウト ガスがないゼロエミッション材料でもあり, 環境面でも優 位性がある。

\section{MEMS 封止実装への応用の利点}

著者らは上記のような面白い特長を持つ発熱多層膜をは んだの溶融熱源として用い, MEMS デバイスの封止実装の ための瞬間はんだ接合法を開発してきた。近年の半導体加 工技術やボトムアップ加工技術の飛躍的進歩の恩恵を受 け, 多種多様な MEMS デバイスが実用されている。電子デ バイスと MEMS デバイスの違いは, 前者が電気信号の授受 のみで何らかの仕事をするデバイスであるのに対し, 後者 は機械的に動く“可動部”を持つことにある。この違い は, MEMS の実装には電子デバイス実装に一般的に用いら れる樹脂封止などの技術をそのまま適用できず，パッケー ジと呼ばれる 箱” の中に収納する必要性が生じることを 示している。接合法には幾つかの方法があるが，比較的低 温プロセスであるはんだ接合を MEMS 封止パッケージに用 いる場合, はんだを溶融させるために，図４に示すように デバイスを内部に収納した状態で全体を電気炉加熱する方 法か, はんだ近傍にヒーター回路を設けてジュール加熱す る方法のいずれかが用いられる。いずれの方法でもデバイ

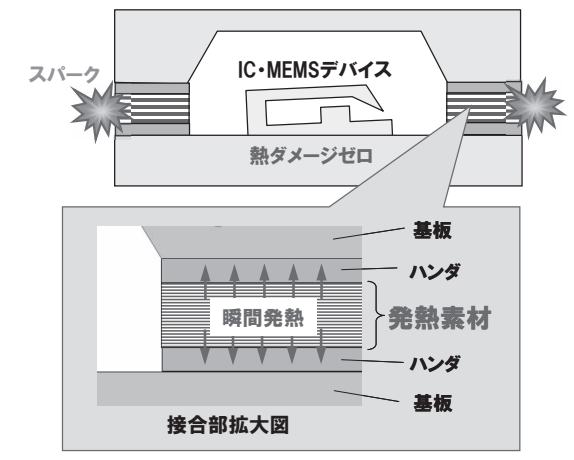

図 4. 瞬間はんだ接合を用いた MEMS 封止パッケージの模 式図

スをパッケージ内部に収納した状態で比較的長時間加熱す ることとなり，異種材料の積層構造を多く持つ MEMS に熱 損傷が及ぶ可能性が高いことが問題である。

この技術課題に対し, 著者らが提案する自己伝播発熱多 層膜を熱源としたはんだ接合でははんだのみを局所的かつ 瞬時に加熱できるため, パッケージ内部のデバイスの熱損 傷を大幅に低減できる可能性が高い。加えてリフロー不要 でアウトガスゼロの省エネ・低エミッションプロセスであ り，実用化されれば環境面への好影響も期待できる。

\section{4. 瞬間はんだ接合技術の問題点}

$\mathrm{Al} / \mathrm{Ni}$ 多層膜を熱源としたはんだ接合 MEMS パッケージ の作製に際し，まず，2 枚の $\mathrm{Si}$ チップの瞬間はんだ接合を 行った。Sn-3.5Ag はんだを成膜した 2 枚の Si チップの片方 に $\mathrm{Al} / \mathrm{Ni}$ 多層膜（原子比 $1: 1$, バイレイヤー厚 $100 \mathrm{~nm}$, 膜 厚 $30 \mu \mathrm{m} ）$ を成膜し，重ねた状態で上方から加圧して真空 中で電気刺激を $\mathrm{Al} / \mathrm{Ni}$ 多層膜に与えた（図 5)。その結果,

Si チップを瞬時にはんだ接合することに成功した。しか し，接合チップをX線透過観察した結果，図 6 のように反 応開始点から放射状にクラックが存在していた ${ }^{3)}$ 。クラッ ク形成は, $\mathrm{Al} / \mathrm{Ni}$ 多層膜が $\mathrm{NiAl}$ 化合物に変化する際の体積 収縮と関係している。 $\mathrm{Al} / \mathrm{Ni}$ 多層膜に刺激を与えると，化 合物生成反応により結晶構造が面心立方格子 (FCC) から体 心立方格子 (BCC) に変化すると同時に格子面間隔が約半分 になる。これより反応後の体積は反応前から約 $12 \%$ 減少 し，この体積収縮がクラック発生の主要因と考えられる。 $\mathrm{Al} / \mathrm{Ni}$ 多層膜の厚みの微妙な変化や膜内の欠陌, 組成么ラ などにより，場所によって反応伝播速度が若干異なる。伝 播速度が速い部分は体積収縮を伴いながら反応が優先的に 進み, 結果として反応伝播が遅い部分にクラックができた ものと推測できる。これに基づくと, 複数点から同時に反 応を誘起した場合, 反応同士が衝突するところに大きなク ラックが形成されると予想できる。自作のマルチプローブ 反応誘起システムで複数点同時反応させた結果, 図 7 のよ うにほぼ予想通りの箇所にクラックを導入することができ た ${ }^{4)}$ 。封止パッケージを視野に入れ，キャビティを持つ $\mathrm{Si}$ 
チップに対しても複数点同時反応させた結果, 同様に反応

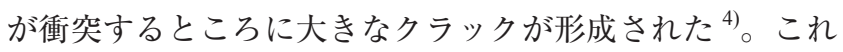
は反応開始位置と数でクラックの位置と向きを制御可能な ことを示唆しており, 仮にダイシングライン上にのみ上手 くクラックを導入できれば, ダイシング後のチップ接合部 はクラックフリー化するものと期待できる。クラックがで きても溶融したはんだが瞬間的に流れ込むため, 接合部に はクラックに基づく空間が存在しない。

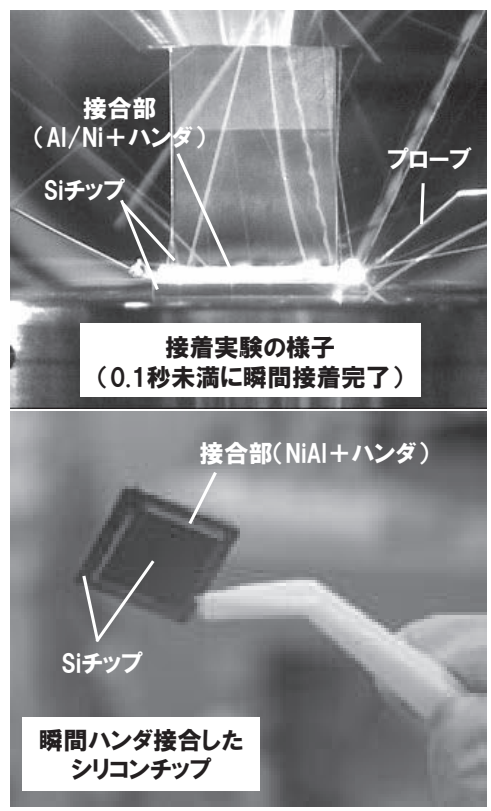

図 5. 自己伝播発熱多層膜を用いた瞬間はんだ接合の様子

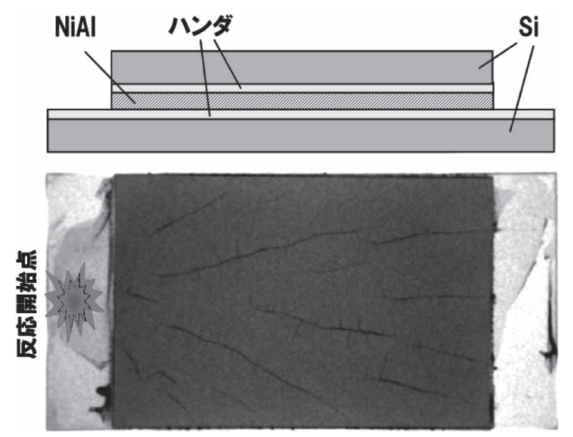

図 6.はんだ接合した Si チップの透過観察写真例
しかし，半導体デバイスの接合ではクラックができると いう事実そのものが敬遠される。 NiAl 化合物内部のクラッ クフリー化を目指し, 著者らは $\mathrm{Al} / \mathrm{Ni}$ 多層膜の線幅, 厚 み，はんだ膜厚を変化させて接合した。その結果， $\mathrm{Al} / \mathrm{Ni}$ 多層膜の膜厚はクラック形成と無関係であったが，接合部 線幅が細く，かつ，はんだが薄すぎない場合，導入された クラックは少なかった（図 8)。この理由は, 線幅が細いほ ど約 $12 \%$ の体積収縮で生じる変形量が小さくなり，はんだ が厚いほどその変形量をはんだが吸収しやすく, 反応時の $\mathrm{Al} / \mathrm{Ni}$ の変形が容易になったためである。しかし，はんだ 厚が $8 \mu \mathrm{m}$ 以上では $\mathrm{Al} / \mathrm{Ni}$ 層の体積収縮時に面内方向だけ でなく面外方向にも変形し，接合後の $\mathrm{NiAl}$ 化合物層は面外 方向に周期的に湾曲していた。加えて NiAl 内部には面外変 形によってもたらされたと思われるボイドが多数確認され た。はんだ層が厚くなるとクラックは抑制されるが NiAl の 変形とボイドが見られ，これらは接合部の機械信頼性低下 をもたらすため避けなければならない。クラックやボイド ができず, NiAl が変形しない最適条件を見出すことが重要 である。

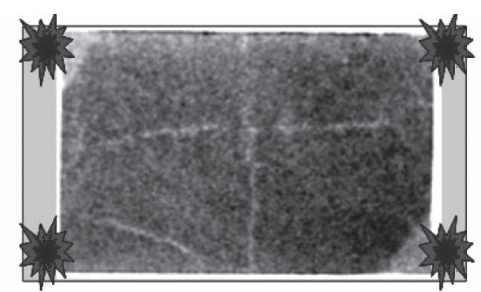

四郪から同時に反応誘起 ＂十字"クラック生成

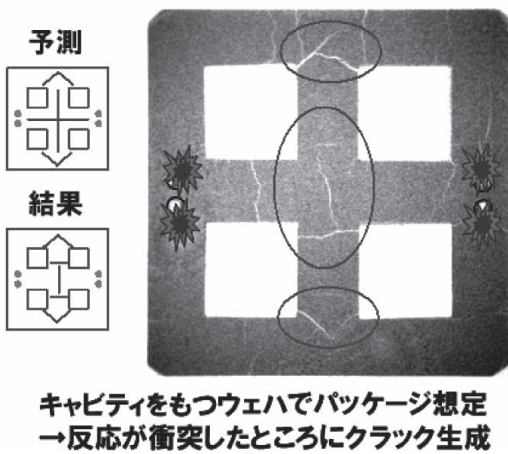

図 7. クラック導入実験の一例

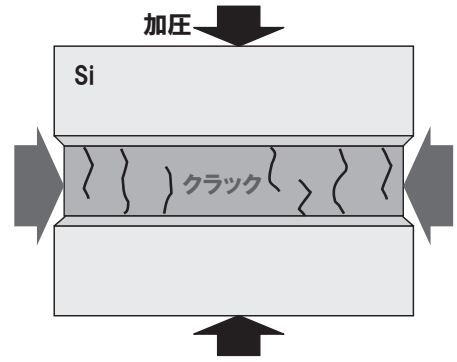

（a）ハン多薄・接合面皘大

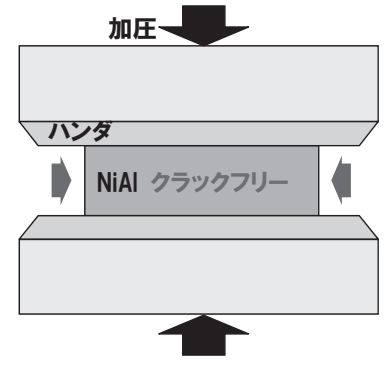

（b）ハンダ中·接合面皘小

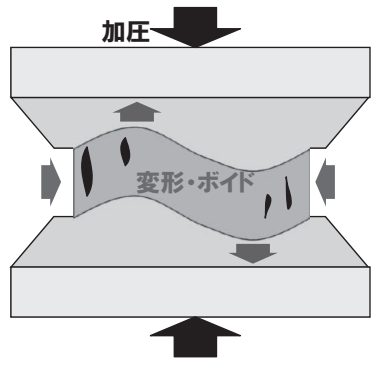

（c）ハンダ厚・接合面皘小

図 8. はんだの厚みと接合面積が NiAl 中のクラックおよびその変形に及ぼす影響の模式図 
（1）接合チップ作製

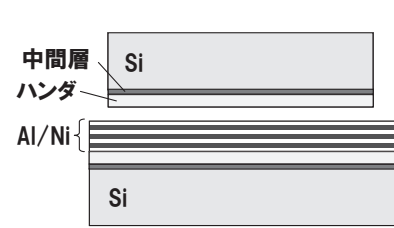

（3）ダイシングカット ダイシングライン
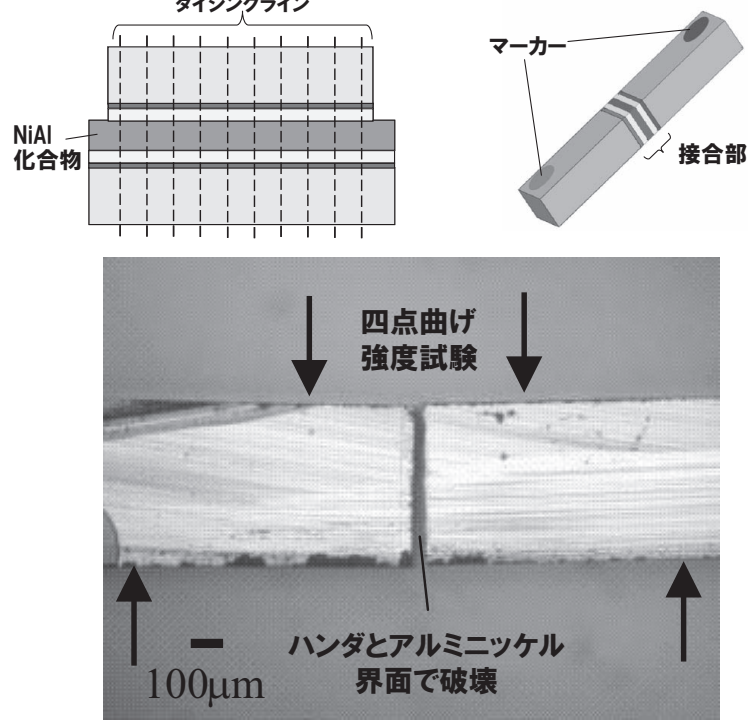

図 9. 四点曲げ試験片作製方法と試験結果の一例

\section{5. 接合強度評価}

はんだ接合を封止構造に使う場合，機械的強度と封止性 の確保は重要である。著者らは瞬間はんだ接合した Si チッ プの接合部をダイシングカットして中央に接合箇所を含む 棒状の試験片を準備し, 四点曲げ試験を行って破壊起点の 特定と最適接合条件を調べた（図 9）。その結果， $\mathrm{Al} / \mathrm{Ni}$ 多 層膜が分厚く, はんだと $\mathrm{Si}$ の間に $\mathrm{Ni} / \mathrm{Cr}$ の下地膜を挟むと

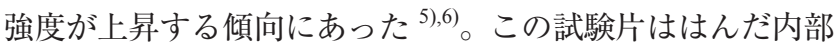
の溶融部と未溶融部の界面が破壊起点であったが，下地膜 が Niのみの試験片ははんだと Si との境界で破壊した ${ }^{7)}$ 。 $\mathrm{NiAl}$ 化合物で壊れた試験片はなく, 反応後の NiAl 化合物 は機械信頼性に優れることを確認した。

\section{2インチSi ウェハを用いた封止パッケージ作製の 試み}

MEMS 封止パッケージに適用することを想定し, デバイ ス収納部を想定したキャビティを複数含む 2 インチ $\mathrm{Si}$ ウェ 八の瞬間はんだ接合を真空中で試みた。図 10 に接合前後の ウェハ表面の写真を示す。この写真は格子状の光をウェハ 表面に照射し, 大気中で撮影したものである。接合前の ウェハ表面のラインパターンは直線であり, ウェハ表面が 平滑なことを示している。一方, 接合後のパターンは曲線 であり，表面に凹凸があることを示唆している。つまり， キャビティ内外の圧力差でメンブレンにたわみが生じた,

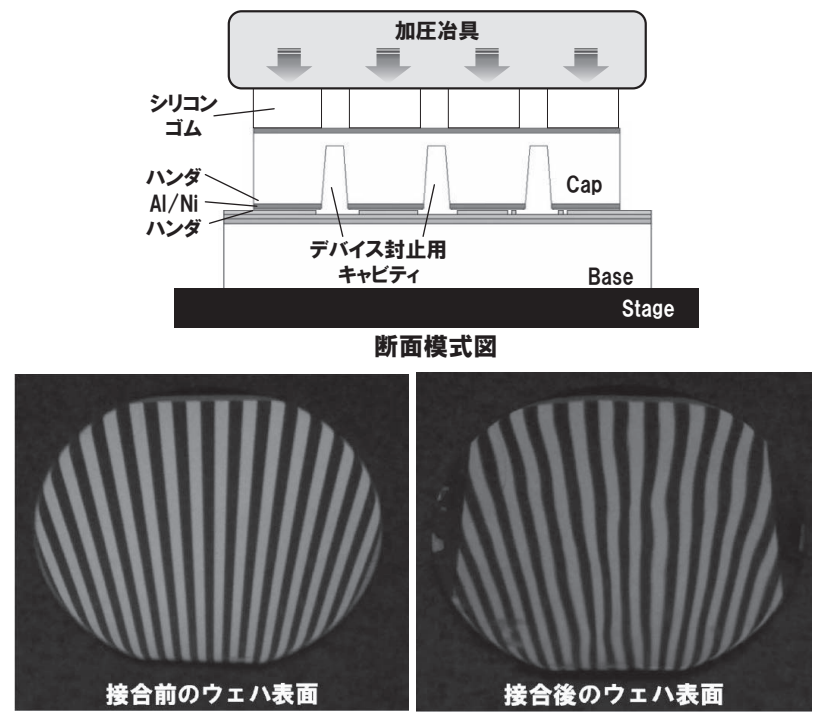

図 10. ダイヤフラム構造を含む 2 インチ Si ウェハの瞬間 はんだ接合結果の一例

すなわち，キャビティ個々の真空封止が実現できたことを 表している。近い将来，瞬間はんだ接合技術が実用される ことを期待する。

\section{7. おわりに}

$\mathrm{Al} / \mathrm{Ni}$ スパッ夕発熱多層膜を用いてはんだを局所的かつ 瞬時に溶融させ，Si ウェハをはんだ接合する技術を概説し た。接合部のクラックフリー化の実現可能性を示唆すると ともに接合強度ならびに封止性能が実用に耐えうる可能性 があることを実験的に確認した。近い将来，微小可動部を 持つ MEMS デバイスの封止パッケージ用はんだ接合法とし て実用され，世界規模で省エネ・低エミッション化が進む ことを期待する。

(2015.9.10- 受理)

\section{文献}

1) T. Namazu, Y. Isono, and T. Tanaka: "Plastic Deformation of Nanometric Single Crystal Silicon Wire in AFM Bending Test at Intermediate Temperatures," Journal of Microelectromechanical Systems, Vol. 11, No. 2, pp. 125-135, 2002

2) T. Namazu, H. Takemoto, H. Fujita, Y. Nagai, and S. Inoue: "SelfPropagating Explosive Reactions in Nanostructured $\mathrm{Al} / \mathrm{Ni}$ Multilayer Films as A Localized Heat Process Technique for MEMS," Proceedings of the 19th IEEE International Conference on Microelectromechanical Systems, MEMS 2006, Istanbul, pp. 286-289, 2006

3) T. Namazu and S. Inoue: "Al/Ni Self-Propagating Exothermic Film for MEMS Application," Materials Science Forum, Vols. 638-642, pp. 2142-2147, 2010

4) T. Namazu, K. Ohtani, K. Yoshiki, and S. Inoue: “Crack Propagation Direction Control of Crack-Less Solder Bonding 
Using AlNi Flash Heating Technique," Proceedings of the 16th International Conference on Solid-State Sensors, Actuators and Microsystems, Transducers 2011, Beijing, pp. 1368-1371, 2011

5) K. Ohtani, Y. Yamano, T. Namazu, and S. Inoue: "Strength Evaluation of Lead-Free-Solder Joint Fabricated by Exothermic Film Local Heating," Proceedings of the 15th International Conference on Solid-State Sensors, Actuators and Microsystems, Transducers 2009, Denver, pp. 172-175, 2009

6) T. Namazu and S. Inoue: “Al/Ni Self-Propagating Exothermic Film for MEMS Application," Materials Science Forum, Vols. 638-642, pp. 2142-2147, 2010

7) T. Namazu, K. Ohtani, S. Inoue, and S. Miyake: “Influences of Exothermic Reactive Layer and Metal Interlayer on Fracture Behavior of Reactively-Bonded Solder Joints," Transactions of the ASME, Journal of Engineering Materials and Technology, Vol. 137, No. 3, 031011 (7 pages), 2015

\section{†用語解説}

自己伝播発熱反応：2 種類の異なる金属から成る多層金 属膜が化合物を形成する際に膜内を自己伝播しながら
生じる発熱反応を指す。軽金属と遷移金属を数 $\mathrm{nm}$ 数十 $\mathrm{nm}$ の厚みで積層堆積させた多層金属膜の一部分 に外部から微小刺激（例えば電気刺激やスパークなど） を与えると，その部分で化合物が生成して発熱する。 局所的に生じた熱が周囲の反応を誘発するエネルギと して働くため, 化合物生成に伴う発熱反応が膜内を自 己伝播する。熱量や速度は2つの金属の組み合わせ, バイレイヤー厚 (1 層ずつの厚み), 総膜厚などによっ て決定される。代表的な自己伝播発熱多層膜には， $\mathrm{Al} /$ $\mathrm{Ni}, \mathrm{Ti} / \mathrm{Al}, \mathrm{Ti} / \mathrm{Si}$ などがある。

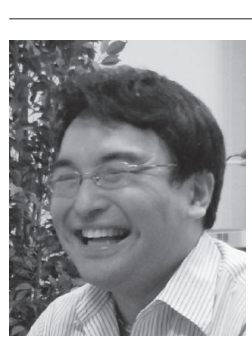

生津資大（なまづ たかひろ）

著者紹介

兵庫県立大学大学院工学研究科機械工学専攻 准 教授

2002 年 3 月, 立命館大学大学院理工学研究科にて 博士（工学）取得後，同年 4 月に兵庫県立大学大 学院工学研究科の助手, 2007 年 4 月に同准教授 (現職)。2 010 年 10 月より 3 年半, JSTささがけ 研究員を兼任。ナノ材料を対象としたMEMS 援用 力学物性計測技術開発と自己伝播発熱素材の基 礎・応用研究を推進。

namazu@eng.u-hyogo.ac.jp

http://www.eng.u-hyogo.ac.jp/mse/mse12/index.htm 